\title{
Nutritional changes of cocoa leaf-based complete feed silage during storage
}

\author{
Mita Arifa Hakim1, Syahriani Syahrir ${ }^{2}$, Asmuddin Natsir ${ }^{2}$ \\ ${ }^{1}$ Student in Postgraduate School, Department of Animal Science and Technology, Faculty of Animal Science, Hasanuddin University \\ ${ }^{2}$ Lecturer in Postgraduate School, Department of Animal Science and Technology, Faculty of Animal Science, Hasanuddin University
}

Correspondence Author: Mita Arifa Hakim, Postgraduate School, Department of Animal Science and Technology, Faculty of Animal Science, Hasanuddin University, Makassar, 90245. Email: mitaarifahakim@gmail.com

Received date: 20 July 2019, Accepted date: 15 September 2019, Online date: 30 September 2019

Copyright: (C) 2019Mita Arifa Hakim et al. This is an open-access article distributed under the terms of the Creative Commons Attribution License, which permits unrestricted use, distribution, and reproduction in any medium, provided the original author and source are credited.

\begin{abstract}
An attempt to increase productivity has been often hindered by limited forage production during dry season. Alternative feed, which is cost-effective and competitive, can be prepared through valorization of agricultural waste such as cocoa leaves, enabling to raise their economic value. This present work aimed to understand the storability of complete feed silage made from cocoa leaves in terms of its nutritional changes during storage. We arranged completely randomized design, while experimental data were then evaluated using Analysis of Variance (Anova). The silage was treated with various levels of storage as follows: 0 week (P1), 2 weeks (P2), 4 weeks (P3), and 6 weeks (P4), and all experimental units were performed at 5 replicates. The silage was then analyzed for nutritional composition (dry matter), crude protein, and crude fiber. As a result, nutritional content of silage differed significantly among treatments. We found that content of dry matter, crude protein and crude fiber decreased gradually until 6 weeks of storage.
\end{abstract}

Keywords: Cocoa leaves, nutrition, storage, complete feed silage

\section{INTRODUCTION}

Livestock production efficiency depends mostly on high-quality feed which is continuously accessed. However, a decline in grazing area and forage production has been the major problems faced by farmers, as a consequence of land-use conversion due to high demand for residential and industrial purposes. To tackle this problem, the utilization of local source for feed production can be highly useful. An alternative source of feed material is by-products of agriculture and plantation, which requires proper processing to convert them into nutritious diet like a commercial one.

As one of the important sectors, cocoa plantation may provide a tremendous contribution to goat farming, since most cocoa biomass (up to $60-75 \%$ ) can be converted into feed [1] In this case, cocoa leaves are promising as main material for feed production. It is important to note that cocoa leaves contain some anti-nutritional compounds such as tannin, a member of plant polyphenols capable of coagulating protein. Although they are rich in crude fiber $(40,03 \%)$, the leaf seems to contain less protein $(9,71 \%)[2]$ which may reduce digestibility [3].

Furthermore, complex of lignin-cellulose needs to consider, that the binding makes cellulose less digested. Thus, an effort is needed to cleavage complex of lignin with cellulose and hemicellulose. The cleavage process can be reached with the aid of microbial actions through fermentation capable of hydrolyzing polysaccharides in cocoa peel [4] reported that the application of cocoa biomass as feed for ruminant animals needs to combine with other nutritional sources, then called as a complete feed, to fullfil all nutrition requirements. For this reason, we introduced complete feed silage. The use of cocoa mass as goat feed could be more time-effective instead of collecting grass and possibly supply feed continuously during dry season[5].

\section{Time And Location}

\section{METHODS}

This study was carried out in November - December 2018. The cocoa leaf-based complete feed silage was prepared in Laboratory of Feed Industry, Faculty of Animal Science, Hasanuddin University. For analysis, Near-Infrared Reflectance Spectroscopy was used to assess level of nutritional content, conducted in Laboratory of Feed Chemistry, Faculty of Animal Science, Hasanuddin University. 


\section{Preparation of Silage}

First, we determined nutritional content of each feed material, as presented in Table 1. Afterwards, experimental feed was made at protein and moisture content of $\pm 11 \%$ and $30 \%$, respectively. The feed sample $(1 \mathrm{~kg})$ was then stored.

Table 1: Chemical composition of raw materials

\begin{tabular}{|c|c|c|c|c|}
\hline No & Materials & Amount $(\%)$ & $\begin{array}{c}\text { Crude protein in } \\
\text { raw material (\%) }\end{array}$ & $\begin{array}{c}\text { Crude protein in the } \\
\text { formulation }(\%)\end{array}$ \\
\hline 1 & Cocoa leaves & 45 & 6 & 2.7 \\
\hline 2 & Rice bran & 30 & 8.2 & 2.54 \\
\hline 3 & Milled corn & 13.5 & 10.8 & 1.35 \\
\hline 4 & Soy pulp & 2.5 & 30.3 & 0.75 \\
\hline 5 & Mollases & 5 & 8.3 & 0.415 \\
\hline 6 & Mineral & 2 & 0 & 0 \\
\hline 7 & Urea & 1 & 287 & 0 \\
\hline 8 & Salt & 1 & 0 & 10.66 \\
\hline
\end{tabular}

Source: Laboratory of feed chemistry, Hasanuddin University

The experiment was made according to complete randomized design, with 4 treatments and 5 replicates. Silage without stored was named as control (P1), while other silage samples were stored at different time levels, i.e. 2 weeks (P2), 4 weeks (P3), and 6 weeks (P4). The observed parameters included chemical composition of dry matter, crude protein, and dietary fiber.

\section{Statistical Analysis}

Data were collected from 20 experimental units (4 treatments, 5 replicates), as mentioned in[6].The mathematical model was described as follows:

$Y_{i j}=\mu+\tau_{i}+\epsilon_{i j}$

where $\mathrm{Y}_{i j}$ is the $i j$ th observation, $\mu$ is overall mean, $\tau_{i}$ is the $i$ th treatment effect, $\epsilon_{\mathrm{ij}}$ is a random error, $i$ is the treatments $(1,2,3$ and 4), while $j$ is the replicates $(1,2,3,4$ and 5).

\section{RESULTS AND DISCUSSION}

As shown in Table 2, we found that the percentage of dry matter between P1 and P2 did not differ significantly, but both levels showed a significant difference compared to P3 and P4. Content of dry matter in silage tended to decline along with storage time. This decline was most likely due to hydrolytic actions induced by microorganisms inside the samples. Some chemical compounds in silage, such as carbohydrate, protein and fat, constituted a good substrate for microorganisms, being a source of energy. Therefore, presence of dry matter was declined as more those compounds were converted into energy by microorganisms.

Table 2: Percentage of dry matter, crude protein, crude silage in cocoa leaf-based complete feed silage after stored in different time levels

\begin{tabular}{|c|c|c|c|c|}
\hline \multirow{2}{*}{ Parameters } & \multicolumn{4}{|c|}{ Treatments } \\
\cline { 2 - 5 } & P1 & P2 & P3 & P4 \\
\hline Dry matter (\%) & $78.44^{\mathrm{c}} \pm 0.39$ & $77.94^{\mathrm{c}} \pm 0.47$ & $73.40^{\mathrm{b}} \pm 1.44$ & $71.44^{\mathrm{a}} \pm 0.58$ \\
\hline Crude protein (\%) & $11.16^{\mathrm{b}} \pm 0.50$ & $9.75^{\mathrm{a}} \pm 0.64$ & $9.98^{\mathrm{a}} \pm 0.50$ & $9.99^{\mathrm{a}} \pm 0.35$ \\
\hline Crude fiber (\%) & $18.61^{\mathrm{b}} \pm 0.59$ & $18.23^{\mathrm{ab}} \pm 0.34$ & $18.88^{\mathrm{b}} \pm 0.59$ & $17.73^{\mathrm{a}} \pm 0.78$ \\
\hline
\end{tabular}

Note: Different superscripts in same row showed a significant difference at $\mathrm{P}<0.05$.

In addition, content of crude protein in P1 (11.16\%) was found as the highest in comparison with P2 (9.75\%), P3 (9.98\%), P4 $(9.99 \%)$. In short, we found that percentage of crude protein decreased during storage, although did not differ significantly (Table 2). The reduction of crude protein is linked to release of $\mathrm{N}$ (present in NPN), while it is also used by microorganisms to synthesize protein for their growth.

Regarding crude fiber, P4 showed the lowest percentage in comparison with other treatments. There was no significant difference in crude fiber content between P1, P2, and P3, as exhibited in Table 2. Fermentation in silage is deemed as the main contributor for alleviation of crude fiber.

Furthermore, based on Table 2, we reported that changes in silage nutrition occurred during storage, which is ascribed to the microbial activity. Silage is rich in moisture content, which serves as proper growth medium for microorganisms. In summary, the higher population of microorganisms need more energy source such as carbohydrate, protein, and fat, contributing to reduction of dry matter. [7] found that reduction of dry matter during storage was also caused by enzymatic activity, microorganism activity, and oxidation, which produce water gasses; therefore, water content tended to raise. Additionally, previous studies also asserted that organic materials such as starch and fat showed a decline during storage since microorganisms used them as source of energy[8. [9]found that reduction of fibers such as cellulose, hemicellulose, and lignocellulose occurred due to enzymatic hydrolysis promoted by bacteria, converting these carbohydrates into simple sugars. This is also in accordance 
with a finding argued by[10], that percentage of crude fibers decreased because of degradation by bacteria. The degradation of crude fibers such as cellulose, lignin, and hemicellulose, was also reported by [11]. In silage, crude fibers act as a source of alternative sugars used by microorganisms for energy generation after other forms of carbohydrate are entirely used up.

\section{CONCLUSION}

Our experimental results demonstrated that the nutritional content of the cocoa leaf-based complete feed silage declined up to 6 weeks of storage. The decrease of dry matter and crude protein occurred at 2 weeks of storage (P2) until the end of experiment at 6 weeks. On the other hand, percentage of crude fiber tended to be unaltered but decreased at the 6 weeks of storage.

\section{REFERENCES}

[1] Gunawan, Sukar, W. I. Werdhany, S. W. Budiarti, S. Widjajanti, T. J. Siswanto, Sutarno, A. Marthon, N. Siswanto, dan R. U. Hatmi. 2012. Pengkajian model pengembangan tanaman kakao integrasi dengan ternak kambing guna meningkatkan produktivitas kakao dan pendapatan petani di Kabupaten Kulon Progo. Balai Pengkajian Teknologi Pertanian, Yogyakarta.

[2] Laconi, A., 1998. Penggunaan Kulit Buah Kakao sebagai Pakan Ternak. Fakultas Peternakan, Institut Pertanian Bogor

[3] Nelson dan Suparjo. 2011. Penentuan Lama Fermentasi Kulit Buah Kakao dengan Phanerochaete chrysosporium : Evaluasi Kualitas secara Kimiawi. Agrinak. 1(1): 1-10

[4] Kuswandi. 2011. Teknologi Pemanfaatan pakan lokal untuk menunjang peningkatan produksi ternak ruminansia. Pengembangan Inovasi Pertanian 4: 189-204

[5] Puastuti, W., Y. Widiawati, and E. Wina. 2015. Digestion and ruminant fermentation of cocoa pod silage based ration enriched by gliricidia and calliandra leaves on goats. Indonesian J. Anim. Veterinary Sci. 20: 31-40.

[6] Gomez, K. A. dan Gomez, A. A. 1984. Statistical Procedures for Agricultural Research. John Wiley \& Sons, Inc. Canada

[7] Suhardjo, L.L. Harper, L.D. Brady and D. Judya. 1986. Pangan, Gizi dan Pertanian. UI-Press, Jakarta

[8] Ardhana, M. 1982. The Microbial Ecology og Tape Ketan Fermentation. Thesis. The University of New South Wales University, Sydney.Buckle, K.A., R.A. Edwards., G.H. Fleet and M. Wootton, 1987. Ilmu Pangan. Terjemahan H. Purnomodan Adiono. UI - Press, Jakarta.

[9] Tillman, A.D, H. Hartadi, S. Reksohadiprojo, S. Prawirokusumo dan S. Lebdosoekojo. 1998. Ilmu Makanan Ternak Dasar. Edisi ke-5. Gadjah Mada University Press, Yogyakarta

[10] Woolford, M.K., 1984. The Silage Fermentation. Marcel Dekker Inc. New York.

[11] Anggorodi, R. 1984. Ilmu Makanan Ternak. Gramedia. Jakarta Woolford, M.K., 1984. The Silage Fermentation. Marcel Dekker Inc. New York. 